\title{
Clinical Profile of Stroke Patients with Vertigo in Hasan Sadikin General Hospital Bandung Neurology Ward
}

\author{
Amany Khansa*, Aih Cahyani**, Lisda Amalia** \\ * Faculty of Medicine Padjadjaran University \\ **Department of Neurology Faculty of Medicine Padjadjaran University \\ Jl. Prof. Eyckman No. 38 Bandung 40161 Indonesia \\ Email : amany15001@mail.unpad.ac.id
}

\begin{abstract}
Vertigo often occurs from the ages of 18 to 79 years with a prevalence of $7.4 \%$. Central vertigo is less common than peripheral vertigo, but it can worsen disability in stroke patients. This study aims to determine the profile of stroke patients with vertigo in Hasan Sadikin General Hospital Bandung Neurology Ward. This is a retrospective descriptive study, using medical record data from 2013 to 2017, and collected 173 medical record data. The results showed that most stroke patients with vertigo were women (59\%), the most age group was 55 64 years (34.1\%), the most common type of stroke was ischemic stroke (75.7\%), the most disturbance regarding the vertebrobasilar system was (72.8\%), the most patients got the first stroke was (52.6\%), $60.7 \%$ of patients suffered from hypertension, $23.1 \%$ of patients suffered from hyperlipidemia 40 (23.1\%), and 22\% of patients suffered from diabetes mellitus type 2. This study concludes that stroke patients who experience vertigo are more common in women, and in the 55-64 year age group. The most common stroke is ischemic in the vertebrobasilar system. Most symptoms in stroke patients with vertigo are dizziness not affected by position, vomiting and nystagmus. Hypertension, hyperlipidemia and diabetes mellitus play an important role in the incidence of stroke in patients.
\end{abstract}

Keywords: vertigo, risk factor, stroke, vertebrobasilar 


\title{
Profil Pasien Stroke dengan Vertigo pada Bangsal Rawat Inap Saraf Rumah Sakit Umum Hasan Sadikin Bandung
}

\author{
Amany Khansa*, Aih Cahyani**, Lisda Amalia*** \\ *Fakultas Kedokteran Universitas Padjadjaran \\ **Departemen Neurologi Fakultas Kedokteran, Universitas Padjadjaran \\ Jl. Prof. Eyckman No. 38 Bandung 40161 Indonesia \\ Email : amany15001@mail.unpad.ac.id
}

\begin{abstract}
Abstrak
Vertigo merupakan gejala yang cukup sering terjadi pada umur 18-79 tahun, dengan prevalensi $7,4 \%$. Vertigo sentral lebih jarang dibandingkan vertigo perifer, namun dapat memperparah disabilitas pada pasien stroke. Penelitian ini bertujuan untuk mengetahui profil pasien stroke yang mengalami vertigo pada Bangsal Rawat Inap Saraf RSUP Dr. Hasan Sadikin Bandung. Penelitian ini merupakan penelitian deskriptif retrospektif menggunakan data rekam medis tahun 2013-2017, dan terkumpul 173 data rekam medis yang memenuhi kriteria. Hasil penelitian menunjukkan, penderita stroke dengan vertigo sebagian besar adalah perempuan (59\%), kelompok umur terbanyak adalah 55-64 tahun (34,1\%), jenis stroke terbanyak adalah stroke iskemik $(75,7 \%)$, gangguan terbanyak mengenai sistem vertebrobasilar $(72,8 \%)$, pasien terbanyak mengalami stroke pertama kali $(52,6 \%), 60,7 \%$ pasien menderita hipertensi, $23,1 \%$ pasien menderita hiperlipidemia $40(23,1 \%)$, dan $22 \%$ pasien menderita diabetes mellitus tipe 2 . Simpulan dari penelitian ini adalah pasien stroke yang mengalami vertigo lebih banyak terjadi pada perempuan dalam kelompok umur 55-64 tahun. Stroke yang sering terjadi adalah iskemik pada sistem vertebrobasilar di bagian pons. Gejala terbanyak pada pasien stroke dengan vertigo adalah pusing berputar tidak dipengatuhi oleh posisi, muntah dan nistagmus. Faktor risiko hipertensi, hiperlipidemia dan DM berperan penting dalam insidensi stroke pada pasien.
\end{abstract}

Kata kunci: vertigo, faktor risiko, stroke, vertebrobasilar 


\section{Pendahuluan}

Pusing merupakan salah satu gejala yang sering dikeluhkan oleh pasien pada poli umum, dengan prevalensi $15-35 \%$ dari keseluruhan populasi. ${ }^{1}$ Pusing merupakan sekelompok gejala yang terdiri dari vertigo, keadaan hampir pingsan, ketidakseimbangan serta pusing yang tidak spesifik lainnya. Vertigo merupakan gejala yang sering terjadi pada umur 18-79 tahun, dengan prevalensi 7,4\% serta kejadian pertahunnya mencapai 1,4\%. Vertigo berasal dari bahasa Latin "Vertere", yang diartikan sebagai "berbalik", merupakan sensasi berputar atau gerakan lain serta dialami secara subjektif pada pasien, salah satu penyebabnya adalah gangguan pada serebrovaskular pada dewasa. ${ }^{1,2}$

Vertigo dapat diklasifikasikan menjadi vertigo perifer dan vertigo sentral. Vertigo sentral lebih jarang terjadi dibandingkan vertigo perifer, namun vertigo sentral dapat menjadi tanda awal penyakit berbahaya pada pasien. ${ }^{1,3,4}$ Vertigo sentral umumnya disebabkan oleh gangguan sistem sirkulasi vertebrobasilar (10,7\%), trauma pada otak (5,2\%), infeksi $(2,9 \%)$, degenerasi spinocerebellar $(1,7 \%)$, tumor serebelum dan batang otak $(0,4 \%) .{ }^{5,6}$ Vertigo sentral yang disebabkan oleh gangguan pada sistem sirkulasi vertebrobasilar, umumnya terjadi di lokasi anatomi yang berhubungan dengan lesi pada batang otak, pons, serebeli dan korteks serebral. ${ }^{1,3}$

Penelitian di Jerman yang melibatkan kelompok usia lanjut, menunjukkan bahwa vertigo menyebabkan disabilitas pada laki-laki $(10,5 \%)$ dan perempuan $(9 \%){ }^{7}$ Disabilitas tersebut mengakibatkan penderita vertigo mengalami keterbatasan dalam melakukan aktivitas sehari-hari (40\%) dan sampai menyebabkan gangguan kejiwaan (28\%), sehingga penderita vertigo mengalami penurunan kualitas hidup dan meningkatkan morbiditasnya. ${ }^{1}$ Sebanyak $10 \%$ pasien stroke mengalami gejala vertigo. ${ }^{8}$ Dua puluh persen dari kasus stroke iskemik terjadi pada bagian pembuluh darah posterior otak (yang menyuplai bagian batang otak, pons dan serebelum) dan $10 \%$ kasus stroke pendarahan terjadi di bagian fossa kranialis posterior. ${ }^{1,} 9$ Berdasarkan uraian di atas, penelitian ini bermaksud untuk meneliti profil pasien stroke dengan vertigo di RSUP Dr. Hasan Sadikin Bandung periode 2013 sampai 2017. Tujuan penelitian ini adalah membantu klinisi dalam mengetahui pencegahan disabilitas pada pasien stroke dan mengurangi tingkat morbiditas.

\section{Metode}

Penelitian ini dilakukan dengan metode deskriptif retrospektif dengan menggunakan data rekam medis pasien Bangsal Rawat Inap Saraf Dr. Hasan Sadikin Bandung. Target penelitian ini adalah rekam medis semua pasien stroke yang mengalami vertigo dan dirawat di bangsal saraf Rumah Sakit Hasan Sadikin, Bandung periode 1 Januari 2013 - 31 Desember 
Research Article

2017. Sebelum dilakukan pengambilan data, aspek legalitas tetap diperhatikan dengan adanya pembuatan surat etik sesuai dengan Komite Etik Fakultas Kedokteran Universitas Padjadjaran dengan nomor 485/UN6.KEP/EC/2018 dan surat izin penelitian sesuai dengan Diklat dan Komite Etik Rumah Sakit Hasan Sadikin, Bandung. Kriteria eksklusi penelitian ini adalah pasien dengan data rekam medis yang tidak lengkap. Pengambilan data dilakukan dari bulan Juli sampai Agustus 2018 dengan metode pengambilan sampel total sampling. Data yang dicari adalah data demografi seperti usia dan jenis kelamin, serta data klinis seperti karakteristik stroke, lokasi lesi (dengan CT Scan atau MRI), rekurensi stroke, ada atau tidaknya faktor risiko stroke (hipertensi, hiperlipidemia dan diabetes mellitus (DM) tipe 2), sifat pusing berputar (dipengaruhi posisi atau tidak), mual dan muntah, diplopia, tinitus, dan nistagmus pada pasien stroke yang mengalami vertigo.

\section{Hasil}

Pada penelitian ini terkumpul 207 pasien stroke dengan vertigo dari tahun 2013 sampai 2017.

Tabel 1 Distribusi Demografi, Karakteristik Stroke dan Faktor Risiko pada Pasien Stroke yang Mengalami Vertigo

\begin{tabular}{cc}
\hline \multicolumn{1}{c}{ Karakteristik } & Total (n) \\
\hline Jenis Kelamin : Laki-laki $\quad$ Perempuan & $71(41 \%)$ \\
Usia (tahun), Rerata (SB) & $102(59 \%)$ \\
$25-34$ & $57,4(12)$ \\
$35-44$ & $4(2,3 \%)$ \\
$45-54$ & $19(11 \%)$ \\
$55-64$ & $47(27,2 \%)$ \\
$65-74$ & $59(34,1 \%)$ \\
$\geq 75$ & $28(16,2 \%)$ \\
Karakteristik Stroke & $16(9,2 \%)$ \\
Iskemik & \\
Sistem Vertebrobasilar & \\
Stroke Pertama & \\
Stroke Ulang & $48(27,7 \%)$ \\
Sistem Karotis & $46(26,6 \%)$ \\
Stroke Pertama & \\
Stroke Ulang & $14(8,1 \%)$ \\
Pendarahan & $23(12,3 \%)$ \\
Sistem Vertebrobasilar & \\
Stroke Pertama & \\
Stroke Ulang & $23(13,3 \%)$ \\
Sistem Karotis & $9(5,2 \%)$ \\
Stroke Pertama & $7(4 \%)$ \\
Stroke Ulang & $3(1,7 \%)$ \\
Faktor Risiko & \\
Hipertensi (Tekanan Darah $\geq 120$ dan $\geq 80 \mathrm{mmHg})$ & $150(86,7 \%)$ \\
Hiperlipidemia (Kolesterol Total $>239 \mathrm{mg} / \mathrm{dL})$ & $40(23,1 \%)$ \\
Diabetes (Diagnosis Rekam Medis) & $38(22 \%)$ \\
\hline & \\
\hline & \\
\hline & \\
\hline & \\
\hline
\end{tabular}




\section{Tabel 2 Distribusi Gejala-gejala yang Berkaitan dengan Vertigo pada Pasien berdasarkan Lokasi Lesi Stroke Iskemik}

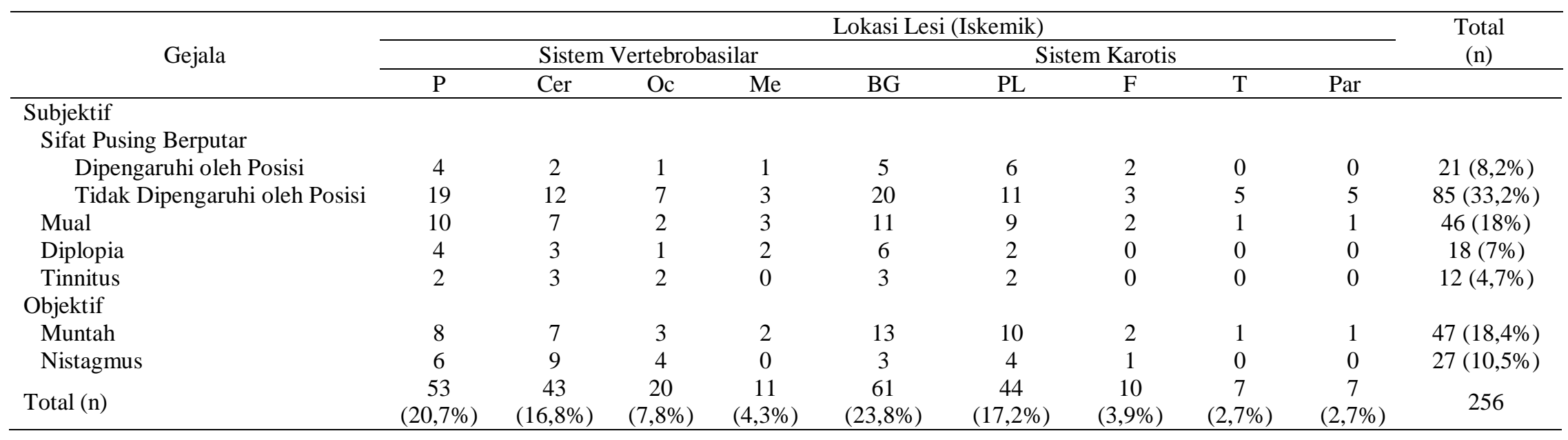

Keterangan :

$\mathrm{P}=$ Pons, $\mathrm{Cer}=$ Serebelum, $\mathrm{Oc}=$ Oksipital, $\mathrm{Me}=$ Mesensefalon, $\mathrm{BG}=$ Basal Ganglia, $\mathrm{PL}=$ Paraventrikular Lateralis, $\mathrm{F}=$ Frontal, $\mathrm{T}=$ Temporal, $\mathrm{Par}=\mathrm{Parietal}$ 
Research Article

Tabel 3 Distribusi Gejala-gejala yang Berkaitan dengan Vertigo pada Pasien berdasarkan Lokasi Lesi Stroke Pendarahan

\begin{tabular}{|c|c|c|c|c|c|c|c|c|c|c|c|c|c|}
\hline \multirow{3}{*}{ Gejala } & \multicolumn{12}{|c|}{ Lokasi Lesi (Pendarahan) } & \multirow{3}{*}{$\begin{array}{c}\text { Total } \\
\text { (n) }\end{array}$} \\
\hline & \multicolumn{6}{|c|}{ Sistem Vertebrobasilar } & \multicolumn{6}{|c|}{ Sistem Karotis } & \\
\hline & $\mathrm{P}$ & Cer & $\mathrm{V}$ & SAH & $\mathrm{Me}$ & $\mathrm{Th}$ & $\mathrm{V}$ & BG & Par & SAH & $\mathrm{T}$ & ICB & \\
\hline \multicolumn{14}{|l|}{ Subjektif } \\
\hline \multicolumn{14}{|l|}{ Sifat Pusing } \\
\hline \multicolumn{14}{|l|}{ Berputar } \\
\hline $\begin{array}{l}\text { Dipengaruhi } \\
\text { oleh Posisi }\end{array}$ & 1 & 0 & 1 & 1 & 0 & 0 & 1 & 0 & 0 & 0 & 0 & 0 & $\begin{array}{c}4 \\
(3,8 \%)\end{array}$ \\
\hline $\begin{array}{l}\text { Tidak } \\
\text { Dipengaruhi } \\
\text { oleh Posisi }\end{array}$ & 12 & 11 & 3 & 1 & 1 & 0 & 4 & 2 & 2 & 1 & 1 & 1 & $\begin{array}{c}39 \\
(36,8 \%)\end{array}$ \\
\hline Mual & 6 & 3 & 1 & 1 & 1 & 0 & 1 & 0 & 0 & 0 & 0 & 0 & $\begin{array}{c}13 \\
(12,3 \%)\end{array}$ \\
\hline Diplopia & 4 & 0 & 0 & 0 & 1 & 0 & 0 & 0 & 0 & 0 & 0 & 0 & $\begin{array}{c}5 \\
(4,7 \%)\end{array}$ \\
\hline Tinnitus & 4 & 0 & 0 & 0 & 1 & 1 & 0 & 0 & 0 & 0 & 0 & 0 & $\begin{array}{c}6 \\
(5,7 \%)\end{array}$ \\
\hline \multicolumn{14}{|l|}{ Objektif } \\
\hline Muntah & 8 & 10 & 4 & 2 & 1 & 0 & 2 & 1 & 0 & 0 & 0 & 0 & $\begin{array}{c}28 \\
(26,4 \%)\end{array}$ \\
\hline Nistagmus & 4 & 4 & 2 & 1 & 0 & 0 & 0 & 0 & 0 & 0 & 0 & 0 & $\begin{array}{c}11 \\
(10,4 \%)\end{array}$ \\
\hline Total (n) & $\begin{array}{c}39 \\
(36,8 \% \\
)\end{array}$ & $\begin{array}{c}28 \\
(26,4 \% \\
)\end{array}$ & $\begin{array}{c}11 \\
(10,4 \%)\end{array}$ & $\begin{array}{c}6 \\
(5,7 \%)\end{array}$ & $\begin{array}{c}5 \\
(4,7 \%)\end{array}$ & $\begin{array}{c}1 \\
(0.9 \%)\end{array}$ & $\begin{array}{c}8 \\
(7,5 \%)\end{array}$ & $\begin{array}{c}3 \\
(2,8 \%)\end{array}$ & $\begin{array}{c}2 \\
(1,9 \%)\end{array}$ & $\begin{array}{c}1 \\
(0,9 \%)\end{array}$ & $\begin{array}{c}1 \\
(0,9 \%)\end{array}$ & $\begin{array}{c}1 \\
(0,9 \%)\end{array}$ & 106 \\
\hline
\end{tabular}

Keterangan :

$\mathrm{P}=$ Pons, Cer $=$ Serebelum, V = Ventrikel, $\mathrm{SAH}=$ Pendarahan Subarakhnoid, Me = Mesensefalon, $\mathrm{Th}=$ Thalamus, BG = Basal Ganglia, Par $=$ Parietal, $\mathrm{T}=$ Temporal, $\mathrm{ICB}=\mathrm{Intraserebrum}$ 
Setelah rekam medis ditelaah kembali, data yang memenuhi kriteria inklusi dan eksklusi sebanyak 39 rekam medis pada tahun 2013, 38 rekam medis pada tahun 2014, 27 rekam medis pada tahun 2015, 42 rekam medis pada tahun 2016, dan 27 rekam medis pada tahun 2017. Sehingga didapatkan sampel total sebanyak 173 pasien periode 1 Januari 2013 sampai 31 Desember 2017.

Pasien stroke yang mengalami vertigo lebih banyak pada perempuan yaitu sebanyak $102(59 \%)$, untuk usia 55-64 tahun 59 (34,1\%). Stroke iskemik pertama kali pada sistem vertebrobasilar $48(27,7 \%)$, dengan faktor risiko hipertensi 150 (86,7\%) (Tabel 1). Tabel 2 menunjukkan bahwa pons merupakan daerah lesi stroke iskemik sistem vertebrobasilar terbanyak $53(20,7 \%)$, sedangkan pada sistem karotis adalah basal ganglia $61(23,8 \%)$. Mual dan muntah menjadi gejala yang sering terjadi sebanyak 46 (18\%) dan 47 (18,4\%), diikuti dengan nistagmus $27(10,5 \%)$. Letak lesi terbanyak untuk sistem vertebrobasilar adalah pons 39 $(36,8 \%)$, sedangkan pada sistem karotis adalah di ventrikel 8 (7,5\%). Gejala terbanyak yakni mual dan muntah sebanyak $13(12,3 \%)$ dan 28 (26,4\%), diikuti oleh gejala nistagmus sebanyak $11(10,4 \%)$ (Tabel 3). Pada penelitian ini, terdapat jumlah lesi yang melebihi dari jumlah subjek, ini disebabkan karena satu pasien dapat memiliki beberapa lokasi lesi stroke. Terutama pada pasien yang mengalami stroke ulang, lesi stroke dapat melebihi dari satu lokasi.

\section{Diskusi}

Pada hasil penelitian ini didapatkan bahwa perempuan lebih banyak menderita stroke dengan vertigo yakni 102 (59\%) dibanding laki-laki. Hasil perbandingan jenis kelamin ini tidak sesuai dengan penelitian yang dilakukan oleh Ozono yang menemukan bahwa penderita vertigo sentral lebih banyak laki-laki $(66,7 \%) .{ }^{10}$ Penyebab laki-laki lebih banyak mengalami stroke dengan vertigo sentral yakni karena angka harapan hidupnya lebih rendah dari perempuan. ${ }^{11}$ Banyaknya perempuan stroke dengan vertigo pada penelitian ini dapat disebabkan rendahnya pendidikan perempuan Indonesia. ${ }^{12}$

Pada karakteristik demografi lainnya, didapatkan pasien dengan umur 55-64 tahun lebih banyak yang mengalami stroke dengan vertigo 59 (34,1\%). Ini sesuai dengan data dari KEMENKES 2014, bahwa pasien stroke lebih banyak pada kelompok umur 55-64 tahun. Hal ini disebabkan karena umur lebih dari 60 tahun memiliki faktor risiko yang lebih banyak untuk menyebabkan stroke dengan vertigo. ${ }^{13}$

Stroke iskemik lebih banyak menyebabkan vertigo dibanding pendarahan sebanyak 131 $(75,7 \%)$, ini sesuai dengan penelitian yang dilakukan Vanni dengan persentase stroke iskemik yang mengalami vertigo sentral sebanyak $21,6 \% .{ }^{14}$ Hal tersebut juga disebabkan oleh jumlah pasien stroke iskemik lebih banyak dibanding pendarahan. ${ }^{15}$ 
Pada penelitian yang dilakukan oleh Sarnowski, stroke berlokasi pada sistem karotis (sirkulasi anterior) lebih banyak yakni 70,9\% dibandingkan sistem vertebrobasilar (sirkulasi posterior) yakni $29,1 \% .{ }^{16}$ Pada penelitian ini sistem vertebrobasilar menjadi lokasi stroke lebih banyak yakni 126 (72,8\%). Hal ini disebabkan karena lokasi bagian otak yang menyebabkan vertigo antara lain; Cranial Nerve (CN VIII), batang otak (mesensefalon, pons, dan medula oblongata) dan serebelum, disuplai oleh sistem vertebrobasilar. ${ }^{17,18}$ Penyebab umum dari insufisiensi sistem vertebrobasilar adalah terbentuknya aterosklerosis pada arteri besar, emboli dan penetrating small-vessel disease. ${ }^{18}$

Rekurensi pada stroke berdasarkan hasil penelitian Pennlert adalah jarang terjadi, hanya sebanyak 13,9\%. ${ }^{19}$ Pada penelitian ini terdapat 73 (42,2\%) rekurensi stroke yang kedua kali, dan $9(5,2 \%)$ untuk yang ketiga kali. Prevalensi rekurensi stroke pada penelitian ini dapat dikatakan cukup tinggi, hal ini diakibatkan oleh faktor risiko pada pasien seperti usia lanjut dan DM. ${ }^{19}$ Faktor risiko vertigo dengan stroke yang umum terjadi adalah hipertensi, hiperlipidemia dan DM. ${ }^{20}$ Penelitian yang dilakukan oleh Qinqin Cao membuktikan bahwa pengendalian hipertensi dengan baik akan menurunkan risiko terjadinya stroke di kemudian hari. ${ }^{21}$ Hipertensi berperan dalam patogenesis stroke pendarahan yakni dengan mengubah struktur pembuluh darah sehingga membentuk aneurisma yang mudah pecah. ${ }^{22}$ Pada stroke iskemik, hipertensi muncul akibat terbentuknya aterosklerosis atau adanya emboli. ${ }^{23}$

Faktor risiko lain rekurensi stroke adalah hiperlipidemia atau kelebihan total kolesterol darah dalam tubuh, hal ini dapat memicu terbentuknya aterosklerosis atau membentuk emboli pada pembuluh darah yang akhirnya dapat menyebabkan stroke iskemik. Aterosklerosis tersebut dapat menyebabkan hipertensi yang nantinya akan memicu terjadinya stroke pendarahan. ${ }^{24} \mathrm{Hal}$ ini sesuai dengan penelitian Kazuo Shigematsu,yang menyatakan bahwa hiperlipidemia dapat menyebabkan peningkatan insidensi stroke iskemik maupun pendarahan. ${ }^{25}$ Kadar kolesterol pasien pada penelitian ini yang umumnya telah terkendali, bukan berarti pasien tidak memiliki aterosklerosis. ${ }^{26}$

DM juga berperan menjadi faktor risiko terjadinya penyakit kardiovaskular pada pasien, ini sesuai dengan penelitian yang dilakukan oleh Dinesh Shah yakni pada kadar HbA1c yang melebihi $7,5 \%$ risiko penyakit kardiovaskular meningkat. ${ }^{27}$ Profil gula darah pasien pada penelitian ini rata-rata normal, walaupun cukup banyak pasien yang didiagnosis DM tipe 2 yakni sebanyak 38 (22\%). Kadar gula darah pasien sebagian besar telah terkontrol dengan baik.

Pada otak, sistem vertebrobasilar memperdarahi bagian yang berfungsi dalam sistem keseimbangan, salah satunya pons. Pons merupakan bagian dari otak tengah menerima saraf eferen dari telinga bagian dalam bersamaan dengan medula, pons juga menerima $C N$ VI yang berhubungan dengan gerakan otot mata, sehingga jika ada stroke pada pons gejala yang muncul 
adalah vertigo dan nistagmus. ${ }^{18,28,29}$ Maka, penting bagi praktisi klinis untuk melakukan pemeriksaan vertigo dan nistagmus untuk memastikan bahwa lokasi lesi stroke berada di pons.

Sistem karotis menunjukkan gejala yang berbeda, sistem ini jarang menyebabkan vertigo pada pasien stroke akibat organ yang disuplai tidak memiliki peran utama dalam sistem keseimbangan tubuh seperti basal ganglia. Basal ganglia merupakan bagian otak yang memiliki fungsi utama mengintegrasi sensorik, motorik, asosiasi dan sinyal limbik untuk menghasilkan perilaku sesuai degan keadaan. Basal ganglia juga berperan dalam menghubungkan sinyalsinyal dari sistem vestibular (seperti nukleus vestibular, thalamus dan korteks). Dengan demikian jika terjadi gangguan pada basal ganglia dapat terjadi gangguan keseimbangan. ${ }^{30}$ Sesuai dengan penelitian ini, pasien dengan stroke pada lokasi basal ganglia dapat menyebabkan vertigo, namun jumlahnya tidak sebanyak lesi pada sistem vertebrobasilar.

Sesuai dengan karakteristik vertigo sentral, dari penelitian ini ditemukan vertigo terbanyak tidak dipengaruhi oleh posisi, karena organ sensoris dari pergerakkan kepala adalah aparatus vestibularis yang berada di telinga dalam. ${ }^{31}$ Hal ini menjadi gejala pembeda utama dari vertigo sentral dan perifer, seperti pada penelitian yang dilakukan oleh Imai. ${ }^{32}$ Mual dan muntah adalah gejala yang sering dialami pada pasien yang menderita vertigo seperti pada hasil penelitian ini. Munculnya mual merupakan akibat dari impuls yang mengaktifkan nukleus fastigial dari traktus vestibuloserebelum serta beberapa area di batang otak (termasuk nukleus motorik vagus dorsal dan area postrema), sedangkan muntah terjadi akibat nukleus parabrakial menerima impuls dari nukleus vestibular dan meneruskannya ke sistem limbik sehingga dapat menggerakkan otot abdomen. ${ }^{33}$

Nistagmus atau pergerakan bola mata secara tidak disadari merupakan gejala khas yang menandakan adanya gangguan pada serebelum; nistagmus horizontal lebih sering ditemukan dibandingkan vertikal atau rotary. Stroke pada vermis serebelum, nucleus prepositus hypoglossi, nukleus vestibular medial, intersitial nucleus of Cajal dan vestibulocerebellum dapat menyebabkan nistagmus vertikal. ${ }^{34}$ Hal ini sesuai dengan hasil penelitian, yang mana banyak ditemukan pasien yang mengalami stroke pada lokasi tersebut mengalami nistagmus. Beberapa data rekam medis memiliki hasil CT Scan atau MRI normal, namun data ini tetap masuk ke dalam kriteria inklusi karena klinisi menegakkan diagnosis berdasarkan anamnesis dan pemeriksaan fisik. Pada kondisi ini dapat dikatakan bahwa pasien mengalami keadaan stroke hiperakut. $^{35}$

Pasca stroke, pasien dapat mengalami perbaikan kondisi dengan berkurangnya tanda dan gejala. Perbaikan kondisi tersebut disebabkan oleh kerja plastisitas otak yang telah rusak akibat stroke. Proses ini diawali dengan perubahan fisik pasca stroke pada lokasi lesi seperti peningkatan aliran darah, edema, metabolisme dan inflamasi yang kemudian diikuti dengan 
proses perbaikan secara endogen. ${ }^{36}$ Regenerasi saraf pada otak dapat terjadi dengan cara pembentukan cabang kolateral saraf yang masih hidup dengan saraf yang lainnya dekat dengan lokasi stroke, dibantu dengan adanya rekonstruksi dendrit, perubahan glia dan vaskulatur dari daerah otak tersebut. Dengan demikian, gejala yang timbul dapat berkurang sesuai dengan kemampuan plastisitas otak pasien. ${ }^{37}$

Prognosis pasien stroke lebih baik pada pasien yang lebih muda, namun tetap dapat mengalami disabilitas dan tidak memiliki kualitas hidup yang lebih baik. Pengobatan hipertensi, DM dan penanganan pasca stroke diperlukan untuk memperbaiki prognosis pasien. ${ }^{38}$ Dengan demikian, prognosis pasien stroke dengan vertigo akan lebih buruk dibandingkan stroke tanpa vertigo, namun hal ini perlu dikonfirmasi kembali menggunakan Dizziness Handicap Inventory $(\text { DHI })^{39}$

\section{Simpulan}

Simpulan dari penelitian ini, pasien stroke yang mengalami vertigo lebih banyak terjadi pada perempuan dalam kelompok umur 55-64 tahun. Stroke yang sering terjadi adalah iskemik pada sistem vertebrobasilar di bagian pons. Gejala terbanyak pada pasien stroke dengan vertigo adalah pusing berputar tidak dipengatuhi oleh posisi, muntah dan nistagmus. Faktor risiko hipertensi, hiperlipidemia dan DM berperan penting dalam insidensi stroke pada pasien. Dari hasil penelitian ini diharapkan klinisi dapat mengetahui lokasi lesi stroke lebih awal dengan melihat karakteristik pasien melalui anamnesis dan pemeriksaan fisik.

Terdapat keterbatasan dalam melakukan penelitian ini yakni data rekam medis yang berada di Rawat Inap Bangsal Saraf Rumah Sakit Dr. Hasan Sadikin tidak lengkap, sehingga banyak pasien yang dieksklusi dari penelitian ini; selain itu tidak terdapat informasi mengenai penggunaan obat-obatan untuk mengontrol DM dan hipertensi pada pasien.

Untuk penelitian selanjutnya disarankan agar pencatatan rekam medis dapat dilengkapi dengan jelas dan diperlukan penelitian kasus dengan metode kohort potong lintang untuk mengetahui keluaran gejala klinis dan disabilitas pasien, serta mengetahui faktor risiko yang berhubungan dengan munculnya vertigo sehingga dapat melakukan tindakan pencegahan.

\section{Daftar Pustaka}

1. Oxford Textbook of Vertigo and Imbalance. Kennard C, editor. United Kingdom: Oxford University Press; 2013. p. $197-203$

2. WHO Certified, The top 10 causes of death: 2017 [Cited: November 2017] [Available from: http://who.int/mediacentre/factsheets/fs310/en/.

3. Karatas M. Vascular Vertigo : Epidemiology and Clinical Syndromes. The Neurologist. 2011;17.

4. Lin HW, Bhattacharyya N. Balance Disorders in the Elderly: Epidemiology and Functional Impact. The Laryngoscope. 2012; 122(8):1858-61.

5. Yin M, Ishikawa K, Wong WH, Shibata Y. A Clinical Epidemiological Study in 2169 Patients with Vertigo. Auris Nasus Larynx. 2008;36:30-5. 
6. Shahrami A, Norouzi M, Kariman H, Hatamabadi HR, Dolatabadi AA. True Vertigo Patients in Emergency Department; an Epidemiologic Study. Emergency. 2016;4(1):25-8.

7. Mueller M, Strobl R, Jahn K, Linkohr B, Peters A, Grill E. Burden of disability attributable to vertigo and dizziness in the aged: results from the KORA-Age study. Eur J of Public Health. 2013;24(5):802-7.

8. Foris LA, Dulebohn SC. Central Vertigo. [Updated 2018 Aug 31]. In: StatPearls [Internet]. Treasure Island (FL): StatPearls Publishing; 2018 Jan-. Available from: //www.ncbi.nlm.nih.gov/books/NBK441861/

9. Elan D. Louis, Mayer SA, Rowland LP. Merritt's Neurology. 13 ed. Philadelphia: Wolters Kluwer; 2015. p.784.

10. Ozono Y, Kitahara T, Fukushima M, Michiba T, Imai R, Tomiyama Y, et al. Differential Diagnosis of Vertigo and Dizziness in the Emergency Department. Acta Oto-Laryngol. 2014;134:140-5.

11. Meirhaeghe A, Cottel D, Cousin Ba, Dumont M-P, Marécaux N, Amouyel P, et al. Sex Differences in Stroke Attack, Incidence, and Mortality Rates in Northern France. J of Stroke and Cerebrovasc Dis. 2017:1-7.

12. Vanni S, Nazerian P, Casati C, Moroni F, Risso M, Ottaviani M, et al. Can Emergency Physicians Accurately and Reliably Assess Acute Vertigo in the Emergency Department? Emerg Med Australas. 2015;27:126-31.

13. Feigin VL, Krishnamurthi RV, Parmar P, Norrving B, Mensah GA, Bennett DA, et al. Update on the Global Burden of Ischemic and Hemorrhagic Stroke in 1990-2013: The GBD 2013 Study. Neuroepidemiology. 2015;45:161-76.

14. Sarnowski Bv, Schminke U, Grittner U, Tanislav C, Böttcher T, Hennerici MG, et al. Posterior versus Anterior Circulation Stroke in Young Adults: A Comparative Study of Stroke Aetiologies and Risk Factors in Stroke among Young Fabry Patients (sifap1). Cerebrovascular Diseases. 2017;43:152-60.

15. Paciaroni M, Agnelli G, Caso V, Bogousslavsky J (eds): Manifestations of Stroke. Front Neurol Neurosci. Basel, Karger, 2012, vol 30, pp 22-25. doi: 10.1159/000333379

16. Baloh RW, Kerber KA. Clinical Neurophysiology of the Vestibular System. 4 ed. Gilman S, editor. New York: Oxford University Press; 2011. p. 319-38.

17. Pennlert J, Eriksson M, Carlberg B, Wiklund P-G. Long-Term Risk and Predictors of Recurrent Stroke Beyond the Acute Phase. Stroke Journal of the American Heart Association. 2014;45:1839-41.

18. Cao Q, Zhou S, Cai B, Wang Q, Zhang J, Shi R, et al. The Impacts of Premorbid Hypertension Treatment on Functional Outcomes of Ischemic Stroke. J Neurol Sci. 2016;363:1-4.

19. Schlunk F, Greenberg SM. The Pathophysiology of Intracerebral Hemorrhage Formation and Expansion. Transl Stroke Res. 2015;6:257-63.

20. Sierra C. Essential Hypertension, Cerebral White Matter Pathology and Ischemic Stroke. Curr Med Chem. 2014;21(19):2156-64.

21. Lee C-C, Su Y-C, Ho H-C, Hung S-K, Lee M-S, Chou P, et al. Risk of Stroke in Patients Hospitalized for Isolated Vertigo : A Four-Year Follow-Up Study. Stroke J Am Heart Ass. 2011;42:48-52.

22. Shigematsu K, Watanabe Y, Nakano H. Influences of hyperlipidemia history on stroke outcome; a retrospective cohort study based on the Kyoto Stroke Registry. BMC Neurology. 2015;15(44):1-6.

23. Wang F, Liu Y, Cong Y, Li P, Li Y, Yan Z, et al. Shift of the Interconnection from the Reaction System of Paraoxonase 1 to the Peroxidation Reaction System of Myeloperoxidase with Hdl-C Levels: A Marker of Atherosclerosis in Patients with Normal Cholesterol Levels. Clinica Chim Acta. 2015;438:370-5.

24. Shah AD, Langenberg C, Rapsomaniki E, Denaxas S, Pujades-Rodriguez M, Gale CP, et al. Type 2 Diabetes and Incidence of Cardiovascular Diseases: A Cohort Study in 1.9 Million People. Lancet Diabetes Endocrinol. 2015;3:105-13.

25. Arboix A. Cardiovascular Risk Factors for Acute Stroke: Risk Profiles in the Different Subtypes of Ischemic Stroke. World J Clin Cases. 2016;3(5):418-29.

26. Emergency Neurology. Karen L. Roos ed. Heidelberg: Springer; 2012 . p.71-84.

27. Haider AS. Unilateral Internuclear Ophthalmoplegia, Strabismus and Transient Torsional Nystagmus in Focal Pontine Infarction. BMJ Case Rep. 2016:1-5.

28. Stiles L, Smith PF. The Vestibular-Basal Ganglia Connection: Balancing Motor Control. Brain Research. 2015;597:180-8.

29. Sherwood L. Human Physiology : From Cells to Systems. 9 ed. Boston, USA: Cengage Learning; 2016. p. $211-$ 24.

30. Imai T, Takeda N, Ikezono T, Shigeno K, Asai M, Watanabe Y, et al. Classification, Diagnostic Criteria and Management of Benign Paroxysmal Positional Vertigo. Auris Nasus Larynx. 2016: 44(1). p. 1-6.

31. Yates BJ, Catanzaro MF, Miller DJ, McCall AA. Integration of Vestibular and Emetic Gastrointestinal Signals that Produce Nausea and Vomiting: Potential Contributions to Motion Sickness. Exp Brain Res. 2014; 232(8); 2455-69.

32. Desai K, Bullock T, Damani R, Bershad E. Vertical Upbeat Nystagmus with Isolated Acute Middle Cerebellar Peduncle Stroke Anatomy and Localization. J Neurol. 2016; 1(1) :1-4.

33. Yaghi S, Herber C, Willey JZ, Andrews H, Boehme AK, Marshall RS, et al. Itemized NIHSS Subsets Predict Positive MRI Strokes in Patients with Mild Deficits. J Neurol Sci. 2015: 358(1-2). p. 211-5. 